\title{
The methamphetamine problem
}

\author{
Commentary on ... Psychiatric morbidity and \\ socio-occupational dysfunction in residents of a drug \\ rehabilitation centre ${ }^{\dagger}$
}

\author{
Niall Galbraith ${ }^{1}$
}

BJPsych Bulletin (2015), 39, 218-220, doi: 10.1192/pb.bp.115.050930

${ }^{1}$ University of Wolverhampton, UK

Correspondence to Niall Galbraith (n.galbraith@wlv.ac.uk)

First received 18 Feb 2015, accepted 16 Apr 2015

(C) 2015 The Author. This is an openaccess article published by the Royal College of Psychiatrists and distributed under the terms of the Creative

Commons Attribution License (http:// creativecommons.org/licenses/by/

4.0), which permits unrestricted use,

distribution, and reproduction in any

medium, provided the original work

is properly cited.

\begin{abstract}
Summary This paper introduces the reader to the characteristics of methamphetamine. Explored within are the drug's effects on those who consume it as well as the history and prevalence of its use. The highly addictive nature of methamphetamine is compounded by its affordability and the ease with which it is produced, with North America and East Asia having become established as heartlands for both consumption and manufacture. The paper discusses recent cultural depictions of the drug and also the role that mental health professionals may take in designing and delivering interventions to treat methamphetamine addiction.
\end{abstract}

Declaration of interest None.

\section{The nature of methamphetamine}

Methamphetamine ('meth') is a stimulant which increases levels of monoamines (particularly dopamine, but also noradrenaline and serotonin) in the central nervous system. Its pharmacological effects occur via a number of neurochemical processes, including disruption of vesicular ${ }^{1}$ and transporter ${ }^{2}$ functioning, through the inhibition of monoamine oxidase ${ }^{3}$ and the facilitation of tyrosine hydroxylase. ${ }^{4}$ Like other stimulants, such as cocaine and amphetamine, it produces feelings of euphoria, alertness and increased energy. Unlike cocaine though, a single dose of methamphetamine sustains these effects for many hours. Methamphetamine can be smoked, snorted, injected or swallowed. The psychological effects of long-term use include hallucinations and delusions, depression, suicidality and aggression. ${ }^{5}$ Withdrawal may exacerbate these symptoms, while also leading to fatigue and intense craving. ${ }^{6}$ Long-term health effects are considerable, and include neural damage and associated cognitive impairment, ${ }^{7}$ cardiovascular damage, ${ }^{8}$ dental disease ${ }^{9}$ and stroke. ${ }^{10}$ The drug is also associated with risky sexual behaviour, resulting in a high prevalence of sexually transmitted disease. ${ }^{11}$ Methamphetamine is also noted for its addictiveness. Evidence shows that addiction occurs more rapidly than with cocaine ${ }^{12}$ and that unlike

'See original paper, pp. 213-217, this issue. with amphetamine, methamphetamine-seeking behaviour may persist even when tolerance is reached. ${ }^{13}$ The trajectory of methamphetamine use over a 10-year period has been found to resemble that of heroin more so than that of cocaine. ${ }^{14}$ Methamphetamine is also associated with criminality $^{15}$ and social decline. ${ }^{16}$ It therefore represents a major public health, social and political dilemma.

\section{Who uses methamphetamine and where?}

Across the world, methamphetamine use as a recreational drug has increased significantly since the 1990s, and it is reported as the second most widely misused substance, exceeded only by cannabis. ${ }^{17}$ In the USA during the 1960 s and 1970s, methamphetamine was produced and trafficked mainly by motorcycle gangs, mostly in California. ${ }^{18}$ Patrons were typically White, male, blue-collar workers, but the drug has since become popular among white-collar workers, students, ethnic minorities and women, ${ }^{19}$ and manufacturing has spread to Midwestern states. ${ }^{20}$ One of the principal factors in its rise is the ease with which it can be manufactured. The chemicals necessary for its production (e.g. methylamine, ephedrine or pseudoephedrine) are relatively easy to obtain, as is the equipment required for the 'cooking' process. This has led to a cottage industry in methamphetamine production, with home-based laboratories being commonly uncovered by law enforcement agencies in 
the USA ${ }^{21}$ and in other parts of the world, particularly in Asia. ${ }^{22}$ In addition to the home lab phenomenon, there exist industrial producers of methamphetamine, who manufacture and transport large quantities of the drug. ${ }^{23}$ In North America, large-scale production occurs in both Mexico and Canada and the product is then brought across the border for sale within the USA. In the USA itself, $4.7 \%$ of respondents to a national survey admit to lifetime use of methamphetamine. ${ }^{24}$

Data from Asia also indicate high levels of use. Japan has a long history of misuse, dating back to the $1940 \mathrm{~s}^{23}$ when military stocks of methamphetamine flooded the market, giving rise to high incidence of misuse among young people. A second epidemic occurred in the 1970s, when use soared among blue-collar workers. This crisis has now stabilised and Japan's methamphetamine users now represent an aging population. Since the 1990s, the popularity of methamphetamine has spread to other East Asian countries. By 2007, $63 \%$ of worldwide methamphetamine seizures occurred within the Southeast Asian region, and it is estimated that half of the world's methamphetamine users are found there. ${ }^{25}$ The Mekong region of Myanmar, close to the border of Thailand and China, is identified as Asia's most prolific production centre for methamphetamine. From there the drug is transported across the borders for sale in neighbouring countries. ${ }^{25}$ In Myanmar, it is usually pressed into pill form, known colloquially as yaba ('crazy medicine'). Thailand has suffered its own epidemic, with methamphetamine treatment admissions rising dramatically in the late $1990 \mathrm{~s},{ }^{26}$ but evidence of increasing methamphetamine use is also found in Brunei, Laos, the Philippines ${ }^{22}$ and Cambodia. ${ }^{27}$

In Europe, the meth epidemic has not yet arrived, perhaps because there is already a congested market for stimulant drugs, although the Czech Republic and to a lesser extent Slovakia have a history of high methamphetamine use. ${ }^{28}$ In Australia, use has increased in recent years but not dramatically. ${ }^{29}$ In South Africa, the past decade has seen a significant increase in treatment admissions for methamphetamine. ${ }^{30}$ This increase in methamphetamine use is positively associated with risktaking sexual behaviour, ${ }^{31}$ which if unchecked may in turn exacerbate an already urgent HIV epidemic.

\section{Cultural depictions of methamphetamine}

The emergence of methamphetamine as one of the most widely used recreational drugs is associated with its rise in the media. Methamphetamine has become a cultural phenomenon, in much the same way that heroin, MDMA (contracted from 3,4-methylenedioxy-methamphetamine; ecstasy) and cannabis had become popularised already. The most obvious cultural reference to methamphetamine is in the hugely successful American drama series Breaking Bad. This drama describes the exploits of a terminally ill chemistry teacher who chooses to become a manufacturer and then seller of methamphetamine, initially to guarantee financial security for his family after his death. The series focuses on the corruption of the main character and the erosion of his relationships with those close to him. What is notable about the series though is that the problem of devastating effects of methamphetamine on individuals and communities occupies only a minor part in the story. The series has done much to publicise the existence of methamphetamine to households across the world, but in not fully exploring its sinister effects (other than the moral degeneration of those who manufacture it), the series runs the risk of sanitising or normalising this destructive drug to the wider society.

At the other extreme, also in the USA, there has been a widely publicised campaign to highlight the unpleasant physical effects of methamphetamine addiction. The 'Faces of Meth' project ${ }^{32}$ exposes police custody photographs of users, showing images of the same individual at different points in time, so as to longitudinally chronicle the ravages of the drug on physical appearance. These before and after photos - which reveal apparently common features of longterm methamphetamine use: skin damage (caused by obsessive picking) and dental ill health (or 'meth mouth' as it is colloquially known $)^{33}$ - are designed to shock and appal observers. The effectiveness of the scheme is difficult to assess due to the absence of trials, however, the use of fear and shock is not always an effective deterrent in health campaigns and is generally regarded as inferior to positive reinforcement approaches. ${ }^{34}$

The Faces of Meth-type approach has come under criticism from Naomi Murakawa, ${ }^{35}$ who argues that its focus on the visual effects of methamphetamine, mostly in White methamphetamine users, represents a type of social panic. Murakawa argues that historically, drug panics in the USA have been constructed in line with racial prejudices (e.g. Chinese-focused opium scares, Mexican-focused cannabis scares and Black-focused crack scares). Methamphetamine addiction is often described along racial lines as a 'White trash' phenomenon. Murakawa claims that decayed or missing teeth mark prevailing fears over the decline in White social status, as traditional representations of American so-called 'White trash' typically depict poor dental health as a visual indicator of lower class.

Given the prevalence of methamphetamine use across the globe, considerable effort has been put into designing effective treatment programmes for its users. Broadly speaking, these interventions are pharmacological, psychosocial or community-based prevention approaches. The evidence in favour of pharmacological treatments is mixed, although some promising findings with modafinil, bupropion and naltrexone have been reported. ${ }^{36}$ Psychosocial interventions have proved effective in the short term, but more evidence is needed to demonstrate long-term benefits. ${ }^{37}$ Community-based prevention schemes have also shown evidence of benefit. ${ }^{38}$ The promise shown by such interventions is encouraging, given the addictiveness of methamphetamine, the intensity and duration of cravings experienced by those who go through withdrawal ${ }^{6}$ and also the psychological comorbidity. Interestingly for mental health professionals, there is evidence that the cost-effectiveness of treatment ${ }^{39}$ and prevention ${ }^{38}$ approaches may compare favourably with alternatives, such as, for example, interventions by law enforcement to disrupt the supply of the precursor chemicals needed for methamphetamine production. ${ }^{40}$ Furthermore, given the advance of this drug across Asia and North America and its 
potential for expansion across thus far untapped markets (e.g. Europe and Africa), the further development of robust treatment programmes for the future is urgently needed.

\section{About the author}

Niall Galbraith is Senior Lecturer in Psychology, University of Wolverhampton, West Midlands, UK.

\section{References}

1 Brown JM, Hanson GR, Fleckenstein AE. Regulation of the vesicular monoamine transporter-2: a novel mechanism for cocaine and other psychostimulants. J Pharmacol Exp Ther 2001; 296: 762-7.

2 Fleckenstein $A E$, Metzger RR, Gibb JW, Hanson GR. A rapid and reversible change in dopamine transporters induced by methamphetamine. Eur J Pharmacology 1997; 323: R9-10.

3 Mantle TJ, Tipton KF, Garrett NJ. Inhibition of monoamine oxidase by amphetamine and related compounds. Biochem Pharmacol 1976; 25 2073-7.

4 Sulzer D, Sonders MS, Poulsen NW, Galli A. Mechanisms of neurotransmitter release by amphetamines: a review. Prog Neurobiol 2005; 75: 406-33.

5 Darke S, Kaye S, McKetin R, Duflou J. Major physical and psychological harms of methamphetamine use. Drug Alcohol Rev 2008; 27: 253.

6 McGregor C, Srisurapanont M, Jittiwutikarn J, Laobhripatr S, Wongtan T, White JM. The nature, time course and severity of methamphetamine withdrawal. Addiction 2005; 100: 1320-9.

7 Barr AM, Panenka WJ, MacEwan GW, Thornton AE, Lang DJ, Honer WG, et al. The need for speed: an update on methamphetamine addiction. J Psychiatr Neuroscience 2006; 31: 301.

8 Kaye S, McKetin R, Duflou J, Darke S. Methamphetamine and cardiovascular pathology: a review of the evidence. Addiction 2007; 102: 1204-11.

9 Shetty V, Mooney LJ, Zigler CM, Belin TR, Murphy D, Rawson R. The relationship between methamphetamine use and increased dental disease. J Am Dent Assoc 2010; 141: 307-18.

10 Rothrock JF, Rubenstein R, Lyden PD. Ischemic stroke associated with methamphetamine inhalation. Neurology 1988; 38: 589-92.

11 Halkitis PN, Parsons JT, Stirratt MJ. A double epidemic: crystal methamphetamine drug use in relation to HIV transmission. J Homosex 2001; 41: 17-35.

12 Castro FG, Barrington EH, Walton MA, Rawson RA. Cocaine and methamphetamine: differential addiction rates. Psychology Addict Behav 2000; 14: 390

13 Shoblock JR, Maisonneuve IM, Glick SD. Differences between d-methamphetamine and $d$-amphetamine in rats: working memory, tolerance, and extinction. Psychopharmacol 2003; 170: 150-6.

14 Hser YI, Huang D, Brecht ML, Li L, Evans E. Contrasting trajectories of heroin, cocaine, and methamphetamine use. J Addict Dis 2008; 27: $13-21$.

15 Cartier J, Farabee D, Prendergast ML. Methamphetamine use, selfreported violent crime, and recidivism among offenders in California who abuse substances. J Interpers Violence 2006; 21: 435-45.

16 Sommers I, Baskin D, Baskin-Sommers A. Methamphetamine use among young adults: health and social consequences. Addict Behav 2006; 31: 1469-76.

17 World Health Organization. Amphetamine-like Stimulants: A Report from the WHO Meeting on Amphetamines, MDMA and Other Psychostimulants, Geneva, 12-15 November 1996. WHO, 1997.

18 Miller MA. History and epidemiology of amphetamine abuse in the United States. In Amphetamine Misuse: International Perspectives on Current Trends (ed. H Klee): 113-34. Harwood Academic Publishers, 1997.
19 Potter MJ, Kolbye KE. Effects of D-Methamphetamine. National Drug Intelligence Center, 1996.

20 Office of National Drug Control Policy. Pulse Check: National Trends in Drug Abuse. ONDCP, 1997.

21 Centers for Disease Control and Prevention. Public health consequences among first responders to emergency events associated with illicit methamphetamine laboratories - selected states, 1996-1999. MMWR 2000; 49: 1021-4

22 Kozel N, Lund J, Douglas J, McKetin R. Patterns and Trends in Amphetamine-Type Stimulants in East Asia and the Pacific 2006. United Nations Office on Drugs and Crime Regional Centre for East Asia and the Pacific, 2007.

23 Anglin MD, Burke C, Perrochet B, Stamper E, Dawud-Noursi S. History of the methamphetamine problem. J Psychoact Drugs 2000; 32: 137-41.

24 Substance Abuse and Mental Health Services Administration. Results from the 2007 National Survey on Drug Use and Health: National Findings. Office of Applied Statistics, NSDUH Series H-34, DHHS Publication No. SMA 08-4343. SAMHSA, 2013.

25 United Nations Office on Drugs and Crime. 2007 World Drug Report. Volume 1: Analysis. United Nations Office on Drugs and Crime, 2007.

26 Devaney M, Reid G, Baldwin S. Situational Analysis of Illicit Drug Issues and Responses in the Asia-Pacific Region. Australian National Council on Drugs, 2006.

27 United Nations Office on Drugs and Crime. Drug Abuse among Youth in Vientiane, School Survey. United Nations Office on Drugs and Crime Regional Centre for East Asia and the Pacific, 2002.

28 Griffiths P, Mravcik V, Lopez D, Klempova D. Quite a lot of smoke but very limited fire - the use of methamphetamine in Europe. Drug Alcohol Rev 2008; 27: 236-42.

29 Degenhardt L, Roxburgh A, Black E, Bruno RB, Campbell G, Kinner S, et al. The epidemiology of methamphetamine risk and harm in Australia. Drug Alcohol Rev 2008; 27: 243-52.

30 Plüddemann A, Myers BJ, Parry CD. Surge in treatment admissions related to methamphetamine use in Cape Town, South Africa: implications for public health. Drug Alcohol Rev 2008; 27: 185-9.

31 Pluddemann A, Flisher AJ, Mathews C, Carney T, Lombard C. Adolescent methamphetamine use and sexual risk behaviour in secondary school students in Cape Town, South Africa. Drug Alcohol Rev 2008; 7: 687-92.

32 Linnemann T, Wall T. 'This is your face on meth': the punitive spectacle of 'white trash' in the rural war on drugs. Theor Criminol 2013; 17 315-34.

33 Hendrickson RG, Cloutier R, John McConnell K. Methamphetaminerelated emergency department utilization and cost. Acad Emerg Med 2008; 15: 23-31.

34 Soames Job RF. Effective and ineffective use of fear in health promotion campaigns. Am J Publ Health 1988; 78: 163-7.

35 Murakawa N. Toothless. Du Bois Review: Soc Sci Res Race 2011; 8 219-28.

36 Karila L, Weinstein A, Aubin HJ, Benyamina A, Reynaud M, Batki SL. Pharmacological approaches to methamphetamine dependence: a focused review. Br J Clin Pharmacol 2010; 69: 578-92.

37 Lee NK, Rawson RA. A systematic review of cognitive and behavioural therapies for methamphetamine dependence. Drug Alcohol Rev 2008; 27: 309-17.

38 Guyll M, Spoth R, Crowley DM. Economic analysis of methamphetamine prevention effects and employer costs. J Studies Alcohol Drugs 2011; 72: 577.

39 Ettner SL, Huang D, Evans E, Rose Ash D, Hardy M, Jourabchi M, et al. Benefit-cost in the California Treatment Outcome Project: does substance abuse treatment 'pay for itself'? Health Serv Res 2006; 41: 192-213.

40 Dobkin C, Nicosia N. The war on drugs: methamphetamine, public health, and crime. Am Econ Rev 2009; 99: 324.

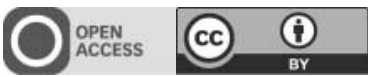

